\title{
Tingkat Kenyamanan Celana Panjang Wanita Ukuran S, M, L di Lembaga Kursus dan Pelatihan (LKP) Happy Banyuwangi
}

\author{
Faizun Nafisah*, Hapsari Kusumawardani, Nur EndahPurwaningsih \\ Universitas Negeri Malang, Jl. Semarang No. 5 Malang, Jawa Timur, Indonesia \\ *Penulis korespondensi, Surel: hapsari.kusumawardani.ft@um.ac.id
}

Paper received: 05-01-2021; revised: 18-01-2021; accepted: 30-01-2021

\begin{abstract}
This study aims to determine the comfort level of women's long pants in S, M, L size at LKP Happy Banyuwangi in terms of static (in a stationary state) and dynamic (in a state of motion). This study uses descriptive methods using a qualitative. The determination of respondents based on body size S, M, L according to the standart size at LKP Happy. The findings indicate that the static aspects of S size have 7 parts of comfortable pants and the dynamic aspects have 17 comfortable positions and 1 comfortable enough position. Then the $\mathrm{M}$ size from the static aspects has 6 parts of comfortable pants and 1 part of calm enough pants, and from the dynamic aspects have 5 comfortable positions, 8 comfortable enough positions, and 5 uncomfortable positions. The last static aspects of L size are 6 parts of comfortable pants and 1-part comfortable enough pants, also from the dynamic aspects 10 comfortable positions, 1 comfortable enough position, and 7 uncomfortable positions. From the results, it shows that the pattern of LKP Happy for women's long pants in S, M, and L size needs to be fixed.
\end{abstract}

Keywords: comfort, long pants, S,M,L size, LKP Happy

\begin{abstract}
Abstrak
Penelitian ini bertujuan untuk mengetahui tingkat kenyamanan celana panjang wanita ukuran $\mathrm{S}, \mathrm{M}$, L di LKP Happy Banyuwangi yang ditinjau dari segi statis (diam) dan dinamis (dalam keadaan bergerak). Penelitian ini menggunakan metode deskriptif menggunakan pendekatan kualitatif. Penentuan responden berdasarkan ukuran tubuh S, M, L sesuai ukuran standar LKP Happy. Hasil Penelitian menunjukkan bahwa pada ukuran S ditinjau dari aspek statis ada 7 bagian celana nyaman, sedangkan untuk aspek dinamis 17 posisi nyaman dan 1 posisi cukup nyaman. Pada ukuran $\mathrm{M}$ ditinjau dari aspek statis ada 6 bagian celana nyaman dan 1 bagian celan cukup nyaman, sedangkan untuk aspek dinamis 5 posisi nyaman, 8 posisi cukup nyaman dan 5 posisi kurang nyaman. Pada ukuran L ditinjau dari aspek statis ada 6 bagian celana nyaman dan 1 bagian celana cukup nyaman, sedangkan aspek dinamis 10 posisi nyaman, 1 posisi cukup nyaman dan 7 posisi kurang nyaman. Kesimpulan dari penelitian ini yaitu, celana panjang wanita menggunakan pola LKP Happy baik untuk ukuran S, sedangkan untuk ukuran M dan L diperlukan adanya perbaikan.
\end{abstract}

Kata kunci: kenyamanan, celana panjang, ukuran S.M.L, LKP Happy

\section{Pendahuluan}

Pendidikan merupakan suatu hal yang sudah umum telah dikenal oleh masyarakat luas. Pendidikan identik dengan belajar suatu materi yang belum dimengerti. Materi yang diajarkan berupa teori maupun praktek. Menurut UU No. 20 tahun 2003 pendidikan di Indonesia dapat melalui 3 jalur yakni formal, informal dan nonformal. LKP/Lembaga Kursus dan Pelatihan) menjadi satu diantara penyelenggara pendidikan pada jalur nonformal, sebagaimana pendapat dari Ambar dan Ambarita (2017) yang menyatakan bahwa pendidikan nonformal menjadi salah satu wujud dari layanan pendidikan yang keberadaannya diperlukan oleh masyarakat, untuk itu perlu adanya persiapan diri agar mampu menyediakan program pendidikan yang telah memenuhi dari fungsi pendidikan formal itu sendiri. Kini pendidikan nonformal 
berkembang pesat di suatu daerah terutama di pedesaan karena disesuaikan dengan kebutuhan penduduknya.

Saat ini, Kabupaten Banyuwangi tengah mengembangkan pendidikan nonformal, dengan adanya usaha pemerintah kabupaten dalam memberikan pelayanan untuk membantu pembelajaran masyarakat dapat diharakan meningkatkan kualitas sumber daya manusia di daerah Banyuwangi. Berdasarkan data dari Dinas Pendidikan Kabupaten Banyuwangi, saat ini jumlah seluruh LKP mencapai 34 tempat dengan beberapa bidang keahlian, kemudian terdapat 2 LKP yang memfokuskan dirinya pada bidang keahlian jahit-menjahit, salah satunya yakni LKP Happy. LKP ini telah didirikan sejak 29 tahun yang lalu, tepatnya pada tahun 1990. Tempat ini menjadi salah satu tempat yang sudah dipercaya untuk melakukan pelatihan, pembelajaran guna untuk membekali keterampilan jahit-menjahit peserta didik serta sebagai tempat uji kompetensi. Berdasarkan hasil observasi beberapa materi di LKP Happy telah diaplikasikan dan sebagai rujukan bahan ajar di SMKN Darul Ulum Muncar, Balai Latihan Kerja Muncar (BLK), SMA Favorit Tegaldlimo, Dinas Pemuda dan Olahraga (Dispora), Dinas Perindustrian dan Perdagangan (Disperindag), karena pemilik LKP telah menjadi tenaga pengajar pada pendidikan formal maupun nonformal tersebut serta menjadi instruktur pada pelatihan yang diadakan oleh kedua dinas tersebut.

Pada tahun 2016 Dispora menyelenggarakan pelatihan yang diikuti ole 25 peserta, kemudian diakhir pertemuan pembelajaran, dinas tersebut membekali mesin jahit untuk setiap individu yang mengikuti pelatihan sebagai bekal usaha mandiri maupun menjalin relasi dengan pihak yang lain. Hal ini dilakukan oleh pemerintah guna mengurangi kuantitas pengangguran. Selain itu, Disperindag melakukan program pelatihan di bidang menjahit dan memberikan bantuan mesin jahit yang berjumlah 6 buah sebagai sarana untuk memperlancar setiap kegiatan yang diselenggarakan oleh Dinas tersebut.

LKP Happy juga memiliki usaha seperti konveksi yang menerima pesanan dari masyarakat berupa kemeja, hem, celana panjang laki-laki maupun wanita, blus, PDH, seragam sekolah, gamis, jaket dan lain sebagainya. Pelanggangnya terdiri dari siswa MtsN 2 Banyuwangi, peserta didik BLK Muncar, siswa SMKN Darul Ulum Muncar, peserta didik LKP Bahasa Inggris Cluring, dan lain sebagainya. Pada penelitian ini, dilakukannya studi pada salah satu materi yang dimiliki oleh lembaga tersebut yaitu celana panjang wanita. Celana menjadi salah satu busana yang populer dan telah digunakan baik untuk kegiatan formal maupun nonformal. Pada zaman dahulu busana bawahan wanita yang biasa di pakai berupa rok, kini celana juga dapat dikenakan oleh wanita kapanpun dan dimanapun, hal ini senada dengan ungkapan dari Dahlia (2015) bahwa wanita dewasa menjadi salah satu pengguna dari celana panjang.

Menurut Ernawati (2008) Definisi dari celana yaitu salah satu diantara busana yang dipakai untuk menutup tubuh bagian bawah, mulai dari pinggang hingga pesak dengan searah yang menyatu, kemudian terpisah diantara dua kaki. Biasanya celana memiliki 4 bagian yaitu 2 lapis bagian muka dan 2 lapis bagian belakang, jadi sisi dan tengah muka dan belakang terdapat kampuh (Maharani dan Hidayati, 2020). Dari opini tersebut, dapatkadisimpulkan bahwa celana menjadi salah satu busana yang dikenakan oleh individu untuk menutupi tubuh bagian luar mulai dai pinggang sampai pesak dengan searah yang menyatu kemudian terpisah diantara dua kaki. 
Pada saat berencana membuat sebuah busana maka, diperlukan adanya pola. "Pola merupakan jiplakan bentuk badan seseorang yang dibuat di atas kain atau kertas yang menggunakan ukuran tertentu dan dijadikan sebagai contoh pada saat menggunting kain supaya tidak terjadi kesalahan" (Hidayah dan Yasnidawati, 2019). Pembuatan pola menjadi salah satu bagian terpenting sebelum membuat busana karena hal ini akan mempengaruhi hasil dari sebuah proses. Hal ini senada dengan pendapat Masruroh (2014) yang mengatakan bahwa hasil akhir dari pembuatan busana yang berlainan kemungkinan dipengaruhi oleh sistem dan teknik pembuatan pola yang berbeda

Pola LKP Happy ini lebih sederhana dalam pembuatannya dengan memerlukan ukuran lingkar pinggang, panggul, paha, lutut, kaki dan panjang celana. Selain itu, terdapat perbedaan dengan sistem lain yakni pada ukuran tinggi panggul yang diperoleh dari hasil pengukuran lingkar pesak dengan cara mengukur ban pinggang depan menuju ban pinggang belakang, lalu setelah memperoleh ukuran tersebut yang awalnya sentimeter diubah ke ukuran inci, angka pada inci inilah sebagai ukuran dari tinggi panggul. Ukuran yang digunakan meliputi ukuran standar maupun ukuran konstruksi. Jika ukuran konstruksi berasal dari ukuran tubuh seseorang sedangkan ukuran standar meruapakan ukuran yang menjadi patokan atau ukuran berdasarkan ukuran tubuh yang dimiliki oleh beberapa orang. Pada penelitian ini ukuran S, M, L menjadi pilihan bagi peneliti karena ketiga ukuran tersebut yang paling umum digunakan (Sutikno, 2012).

Penelitian ini mendeskripsikan tentang tingkatakenyamanan celana panjang dengan menggunakan pola LKP Happy, serta size mana yang cenderung nyaman ketika digunakan oleh si pemakai. Kenyamanan erat hubungannya dengan perasaan seseorang karena mengenai suatu hal yang sedang dirasakan, seperti pendapat Vorensia (2019) Tiap individu memiliki persepsi sendiri tentang kenyamanan yang dirasakan dan disesuaikan dengan kondisi perasaan individu tersebut. Jika dihubungkan dengan celana, maka saat memakai celana tersebut akan timbul rasa enak atau menikmati tanpa adanya suatu hal yang mengganggu. Menurut Hanifah dan Ernawati (2019) salah satu faktor dari kenyamanan busana adalah yang berukuran tepat, tidak sesak ataupun longgar. Pendapat lain berasal dari Irmayanti (2017) yang mengemukakan bahwa ketika bergerak, busana yang dipakai tidak boleh terlalu sempit. Berdasarkan latar belakang tersebut peneliti ingin mengetahui tingkat kenyamanan celana panjang wanita yang ditinjau dari aspek statis (dalam keadaan diam) dan aspek dinamis (dalam keadaan bergerak).

\section{Metode}

Deskriptif dengan pendekatan kualitatif menjadi pilihan peneliti dalam melakukan penelitian, karena hasilnya disusun secara deskripsi berbentuk narasi. Alasan dilakukannya penelitian ini untuk mengetahui tingkat kenyamanan celana panjang wanita dengan pola LKP Happy mulai dari ukuran standar yang ditentukan, pola celana yang digunakan, dan teknik jahit yang diterapkan. Sasaran dari penelitian ini yakni seseorang yang memiliki ukuran tubuh S, M, L sesuai ukuran standar LKP Happy. Sampel yang diambil berupa sampel purposive karena pengambilannya berdasarkan pertimbangan tertentu. Sumber data primer berasal dari responden yang telah diwawancarai, sedangkan data sekunder didapat dari dokumen tentang LKP Happy, buku, serta foto sebagai bahan pendukung. Akumulasi data dilakukan dengan tanya-jawab, pengamatan dan dokumentasi. Analisis data berupa reduksi, penyajian dan verifikasi data, untuk pengecekan keabsahan data dengan uji kredibilitas (informasil yang diterima dapat dipercaya) menggunakan dua acara yakni meningkatkan ketekunan dengan 
memeriksa kembali data yang diperoleh dan triangulasi teknik. Menurut Sugiyono (2017) uji kredibilitas data dapat dilakukan dengan memeriksa data yang diperoleh kepada narasumber yang sama namun menggunkan cara yang berlainan.

\section{Hasil dan Pembahasan}

Hasil dari penelitian ini berupa tingkat kenyamanan celana panjang wanita dengan pola LKP Happy ukuran S, M, L yang ditinjau melalui 2 kriteria yaitu statis (saat responden dalam keadaan diam) dan dinamis (saat responden dalam keadaan bergerak) sebagai berikut

\subsection{Ukuran S}

\subsubsection{Kenyamanan statis}

Tingkat kenyamanan statis meliputi lingkar (pinggang, panggul, pesak, lutut, pipa celana dan kaki). Pada size S ditinjau dari aspek statis nyaman di bagian lingkar pinggang karena kedudukan lingkar pinggang persis pada garis pinggang. Hal ini selaras dengan pendapat dari Aldrich dalam Sutikno (2012) bahwa "lingkar pinggang pas pada garis pinggang dan tak menggelembung". Pada sistem ini terdapat sambungan di bagian pinggang belakang yang dijahit agak masuk ke dalam sekitar $0,5-075 \mathrm{~cm}$. kemudian, lingkar panggul tepat pada garis panggul dan ukurannya cukup. Lingkar paha tepat pada garis paha dan ukurannya cukup. Kedudukan lingkar pesak tepat pada garis pesak, ukurannya cukup serta sekeliling lingkar pesak rapi tanpa ada kerutan. Tinggi panggul pada celana ini diperoleh dari hasil pengukuran lingkar pesak yang sudah diukur keliling dari ban pinggang depan menuju ban pinggang belakang, hasil dari pengukuran tersebut yang awalnya centimeter diubah menjadi ukuran inchi, lalu angka pada inchi tersebut sebagia patokan tinggi panggul atau tinggi pesak. Sebagiamana pendapat dari Masruroh (2014) bahwa hasil akhir dari pembuatan busana kemungkinan dipengaruhi oleh sistem dan teknik pembuatan pola yang berbeda

Pada ukuran S ini bagian pipa celana jatuhnya lurus, rapi, tidak terdapat kerutan serta ukurannya cukup. Selanjutnya, untuk lingkar lutut pas pada garis lutut dan ukurannya cukup. Garis lutut diperoleh dari panjang celana dibagi menjadi dua kemudian di naikkan $4 \mathrm{~cm}$. pengamatmeraba antara garis lutut pada celana dan lutut responden dan hasilnya tidak terdapat kesenjangan antara keduanya. Lingkar kaki pas di bawah mata kaki dan ukurannya cukup, serupa dengan pendapat dari Wright dalam Widiastutik (2013) yang mengatakan bahwa lingkar kaki tampak rata, tidak terlalu sempit dan pas di bawah mata kaki.

\subsubsection{Kenyamanan Dinamis}

Pada kenyamanan dinamis, gerakan yang dilakukan oleh repsonden saat memakai celana panjang ini ada 18 gerakan meliputi duduk di kursi (kedua kaki sejajar, salah satu kaki berada di atas, kedua kaki terbuka) duduk di lantai (bersila, kedua kaki dilekukkn ke depan, kedua kaki dilekukkan ke samping, selonjoran), jongkok, berdiri (berjalan, berlari, salah satu lutut dilekukkan ke depan, kaki digerakkan kedepan, kaki digerakkan ke smaping, kaki digerakkan ke belakang) serta melakukan gerakan sholat (duduk tasyahud akhir, duduk diantara dua sujud, rukuk, sujud,). Dari 18 aktivitas di atas 17 aktivitas masuk kategori nyaman Hal ini sependapat dengan Irmayanti (2017) yang mengemukakan bahwa ketika bergerak, busana yang dipakai tidak boleh terlalu sempit, kemudian 1 gerakan yang menyatakan bahwa cukup nyaman yakni saat duduk di kursi dengan kedua kaki terbuka karena lingkar pesak 
sedikit sempit sehingga menimbulkan sedikit gangguan pergerakan pada tubuh, namun hal ini dapat ditoleransi oleh responden.

\subsection{Ukuran $\mathbf{M}$}

\subsubsection{Kenyamanan statis}

Berdasarkan aspek statis (diam) hasil penelitian menunjukkan bahwa lingkar pinggang kedua responden terletak tepat pada garis pinggang. Posisi lingkar panggul tepat pada garis panggul dan ukuran lingkar panggul cukup. Hasil jadi lingkar panggul dapat menyesuaikan bentuk panggul responden. Posisi lingkar paha terletak pada paha terbesar model yang memakai celana, tidak terdapat adanya gelombang. Selaras dengan gagasan Srikandi \& Rosmiaty (2017) bahwa lingkar paha yang baik yakni yang pas tanpa adanya gelombang. Kedudukan lingkar pesak menunjukkan posisinya sedikit naik, ukuran pada lingkar pesak cukup dan sekeliling lingkar pesak rapi dan tidak ada kerutan. Letak lingkar lutut pas pada garis lutut dan ukurannya cukup. Berdasarkan data yang telah di dapat pipa celana jatuhnya lurus, rapi, tidak terdapat kerutan dan ukurannya cukup. Senada dengan opini dari Wright dalam Widiastutik (2013) bahwa "jatuhnya pipa celana bagian sisi tidak tertarik, dan tak nampak kerutan. Bagian lingkar kaki hasil penelitian membuktikan bahwa lingkar kkai tepat di bawah garis mata kaki dan ukuran pada lingkar kaki cukup.

\subsubsection{Kenyamanan dinamis}

Menurut Alfiah dan Rusanti (2017) "kenyamanan menjadi hal penting ketika seseorang memakai pakai dalam kurun waktu yang lama" maka dari 18 gerakan yang telah dilakukan oleh responden saat memakai celana panjang ini, maka dapat dikategorikan sesuai tingkat kenyamanan yang dirasakan oleh responden. Berikut ini merupakan penjabarannya:

\subsubsection{Posisi nyaman}

Responden merasakan kenyamanan pada 5 posisi yaitu duduk di kursi (kedua kaki sejajar), berjalan, berdiri (salah satu kaki digerakkan ke depan, samping dan belakang). Hasil ini diperoleh berdasarkan seluruh komponen celana nyaman ketika digunakan untu beraktivitas ataupun jika ada bagian yang dirasa sedikit menggangu namun hal ini tidak berpengaruh pada pergerakan responden. Sebagaimana yang telah dikemukakan oleh Irmayanti (2017) pada saat bergerak, busana tidak boleh sempit. Seperti halnya penelitian yang dilakukan oleh Srikandi dan Rosmiaty (2017) responden yang memiliki ukuran sedang dapat merasakan kenyamanan saat berdiri dan melangkah.

\subsubsection{Posisi cukup nyaman}

Hasil penelitian menyatakan bahwa responden merasa cukup nyaman pada 8 posisi yang telah dilakukan yaitu saat duduk di kursi (salah satu kaki berada di atas), bersila, duduk di lantai (kedua kaki dilekukkan ke depan), selonjoran, berlari, rukuk, sujud, duduk diantara dua sujud. Hasil ini berdasarkan apabila terdapat bagian yang sedikit bermasalah sehingga memberikan sedikit pula dampak pada pergerakan responden namun masih dapat ditoleransi, seperti halnya pendapat dari Vorensia (2019) yang menyatakan bahwa tiap individu memiliki persepsi sendiri tentang kenyamanan yang dirasakan dan disesuaikan dengan kondisi perasaan individu tersebut 


\subsubsection{Posisi kurang nyaman}

Terdapat 5 posisi kurang nyaman saat duduk di kursi (kedua kaki terbuka), duduk di lantai (kedua kaki dilekukkan ke samping), jongkok, berdiri (salah satu kaki dilekukkan ke depan) dan duduk tasyahud akhir. Hasil ini diperoleh berdasarkan apabila terdapat bagian yang bermasalah sehingga mengganggu aktivitas responden saat memakai saat memakai celan tersebut. Pada beberapa posisi di atas bagian ban pinggang belakang bervolume dan menggelembung.

\subsection{Ukuran L}

\subsubsection{Kenyamanan statis}

Ditinjau dari segi statis (saat responden dalam keadaan diam) hasil penelitian menunjukkan bahwa lingkar pinggang pas pada garis pinggang dan ukurannya cukup. Pada panggul tepat di garis panggul dan ukurannya cukup. Pada bagian paha pas pada garis paha dan ukurannya cukup, sebagimana pendapat dari Rosmiaty dan Srikandi (2017) yang menyatakan bahwa lingkar paha yang baik yakni yang pas tanpa adanya gelombang. Berdasarkan data yang telah diperoleh lingkar pesak sedikit naik, ukuran lingkar pesak cukup, sekeliling lingkar pesak rapi. Selanjutnya, untuk posisi lingkar lutut pas pada garis lutut dan ukurannya cukup, hasil ini seperti pernyataan dari Wright dalam Widiastutik yang menyatakan bahwa "ciri dari celana yang bagus yakni bagian lutut terletak pada pas pada garis lutut dan sekelilingnya lingkar lutut tak nampak kerutan.".

Pada bagian pipa celana lurus, rapi, tidak terdaat kerutan, dan ukuran pipa celana cukup. Seperti halnyan pendapat dari Maulidia dan Suhartini (2017) kriteria pipa celana yang bagus yakni yang memiliki bentuk pas dan mengecil serta pad di bagian lingkar kaki. Pada bagian lingkar kaki hasil penelitian membuktikan bahwa letaknya tepat di bawah garis mata kaki da ukurannya cukup, serupa dengan gagasan dari Aldrich dalam Sutikno (2012) yang menyatakan bahwa "bagian lingkar bawah kaki rata, lingkar kaki tidak terlalu ketat, dan posisinya pas di bawah mata kaki

\subsubsection{Kenyamanan dinamis}

Pada kenyamanan dinamis (saat responden dalam keadaan bergerak) terdapat 18 gerakan yang dilakukan oleh si pemakai celana panjang ini. Terdapat perbedaan hasil antara kenyamanan statis dan dinamis, karena responden dapat merasa nyaman ketika nyaman namun belum tentu saat bergerak merasa nyaman pula.

\subsubsection{Posisi nyaman}

Terdapat 10 posisi nyaman menurut responden yaitu pada saat duduk di kursi (kedua kaki sejajar, salah satu kaki berada di atas dan kedua kaki terbuka), seperti halnya penelitian yang dilakukan oleh Vorensia (2019) responden yang memiliki ukuran tubuh besar masih nyaman saaat duduk di kursi. Selain itu, posisi yang lain meliputi bersila, duduk di lantai (kedua kaki dilekukkan ke samping), berjalan, berlari, berdiri (salah satu kaki digerakkan ke depan, samping dan belakang). Kenyamanan yang dirasakan responden sebagiamana pendapat dari Hanifah dan Ernawati (2019) salah satu faktor dari kenyamanan busana adalah yang berukuran tepat, tidak sesak ataupun longgar. Pada seluruh posisi di atas narasumber 
merasakan kenyamanan pada level teratas, sehingga mudah dalam melakukan aktivitas tersebut.

\subsubsection{Posisi cukup nyaman}

Pada size L ini hanya terdapat 1 posisi cukup nyaman yakni pada saat rmelakukan rukuk dalam gerakan sholat. Posisi tersebut dirasakan responden cukup nyaman karena terdapat bagian yang sedikit bermasalah dan sedikit berdampak namun hal ini masih dapat ditoleransi.

\subsubsection{Posisi kurang nyaman}

Data yang telah didapatkan menunjukkan bahwa terdapat 7 posisi kurang nyaman meliputi duduk di lantai (kedua kaki dilekukkan ke depan), selonjoran, jongkok, berdiri (satu kaki dilekukkan ke depan), duduk tasyahud akhir, duduk diantara dua sujud, rukuk dan sujud. Pada seluruh posisi di atas responden merasa kurang nyaman karena terdapat bagian celana yang mengganggu pergerakan serta merasa sulit saat menggangu aktivitas. Menurut Rosmiaty dan Srikandi (2017) untuk ukuran besar perlu adanya perubahan model maupun ukuran.

\section{Simpulan}

Pada size S jika ditinjau dari aspek statis (diam) maka terdapat 7 bagian celana yang nyaman, jika ditinjau melalui aspek dinamis (bergerak) maka terdapat 17 posisi yang nyaman dan 1 posisi yang cukup nyaman. Pada size M jika ditinjau dari aspek statis (diam) maka terdapat 6 bagian nyaman dan 1 bagian cukup nyaman sedangkan jika ditinjau dari aspek dinamis (bergerak) terdapat 5 posisi nyaman, 8 posisi cukup nyaman dan 5 posisi kurang nyaman. Pada size L jika ditinjau dari aspek statis (diam) maka terdapat 6 bagian nyaman dan 1 bagian cukup nyaman sedangkan jika ditinjau dari aspek dinamis (bergerak) terdapat 10 posisi nyaman, 1 posisi cukup nyaman dan 7 posisi kurang nyaman. Berdasarkan paparan di atas maka celana panjang wanita sistem LKP Happy ini baik untuk ukuran small (S) dan untuk ukuran M dan L perlu adanya perbaikan pola

\section{Daftar Rujukan}

Alfiah, C., \& Russanti, I., (2017). Perkembangan Desain Busana Pengantin Pinjung IrassPutri Bojonegoro. Jurnall Tata Busana (JTB), 6(3): 32-40

Ambar, V., \& Ambarita, A., (2017). Sistem Informasi Pengolahn Data lulusan Siswa Nonformal Berbasis WEB Pada Dinas Pendidikan Nasiaonal Kota Ternate. Indonesian Journal on Information System (IJIS), 2(1)

Dahlia, D. (2015). Kesesuaian Pola Celana Sistem Charmant Pada Wanita Dewasa Dengan Bentuk Panggul "S" Hal. 2-16 (online), (https;// ejournal.unp.ac.id/index.php/ihet/article/view/4447Padang), diakses 14 April 2020

Ernawati, E. (2008). Tabus Untuk SMK Jilid 1. Jakarta: Direktorat Pembinaan Sekolah Menengah Kejuruan (SMK)

Hanifah, H. \& Ernawati, E. (2019). Kesesuaian Pola SistemmCharmant Pada Wanita Dewasa Indonesia Bertubuh Ideal. Gorga Jurnal Seni Rupa. (GJSR), 8(2): 358-362

Hidayah, N., \& Yasnidawati. (2019). Penyesuaian Pola Dasar Busana Sistem Indonesia untuk Wanita Indonesia Dengan Bentuk Badan Gemuk. Gorga Jurnal Seni Rupa (GJSR). 8(1): 223-230.

Irmayanti, I. (2017). Analisa Perbedaan Titik Pas Antara Pola Sonny \& Pola Praktis Pada Jas Wanita. Makasar: UNM

Maharani, M.A., \& Hidayati, L., 2020. Perbedaan Hasil Jadi Celana Kulot Antara Metode Pola Zero Waste dengan Pola Porrie Menggunakan Bahan Berkotak. Jurnal Tata Busana (JTB), 9(1): 15-20

Masruroh, M. (2014). Komparasi Hasil Pembuatan Kemeja Menggunakan Pola Sistem M.H Wancik \& Soekarno. FFAJ, (3)1 
Jurnal Inovasi Teknik dan Edukasi Teknologi (JITET), 1(1), 2021, 76-83

Maulidina, P.A., \& Suhartini, R., (2017). Perbaikan Sarouel Pants dengan Metode Winifred Aldrich. Jurnal Tata Busana (JTB), 6(2): 15-25

Rosmiaty, R. \& Srikandi, S. (2017). Analisis Pola Celana Sistem Soekarno \& Joseph Dalam Pembuatan Pola Busana Pria. Seminar Nasional LP2M UNM, 510-514

Sugiyono, S. (2017). Metodologi Penelitian, Kuatlitatif, Kuantitatis, RdanD. Bandung; Alfabeta

Sutikno, Y.M., (2012). Analisa Tingkat Kenyamanan Celana Wanita Sistem Soekarno pada Tubuh ukuran S, M ,dan L. Skripsi tidak diterbitkan. Malang: UM

Undang Undang No.20 Tahun 2003 tentang Sistem Pendidikan Nasional (online). (https:// hukum.unsrat.ac.id /uu/uu_20_03.htm) diakses 3 Nopember 2019

Vorensia, S. (2019). Analisis Tingkat Kenyamanan Celana Panjang Wanita Menggunakan Pola Praktis \& Porrie Pada Ukuran XXL. Skripsi tidak diterbitkan. Malang: FT UM

Widiastutik, Y. (2013). Analisis Pembuatan Celana Panjang Wanita Menggunakan Pola Sistem Porrie Muliawan \& Soekarno Ditinjau Dari Titik Pas pada Ukuran "M" Standar Nasional Indonesia. Skripsi tidak diterbitkan. Malang: FT UM 